\title{
Fertilization With Nitrogen, Phosphorus and Potassium on Soil Fertility and Nutritional Status of Yellow Passion Fruit Plants
}

\author{
Rodrigo T. M. Miyake ${ }^{1}$, William H. S. Takata ${ }^{2}$, Nobuyoshi Narita ${ }^{3} \&$ José E. Creste $^{2}$ \\ ${ }^{1}$ Universidade of Estado of Mato Grosso, Nova Xavantina, MT, Brazil \\ ${ }^{2}$ Universidade of Oeste Paulista, Presidente Prudente, SP, Brazil \\ ${ }^{3}$ São Paulo Agency of Agribusiness Technology, Presidente Prudente, SP, Brazil \\ Correspondence: Rodrigo T. M. Miyake, Universidade of Estado of Mato Grosso, Nova Xavantina, MT, Brazil. \\ Tel: 55-018-99615-8865. E-mail: rodrigomaruki@hotmail.com
}

\author{
Received: January 3, 2019 \\ Accepted: February 6, $2019 \quad$ Online Published: April 15, 2019 \\ doi:10.5539/jas.v11n5p142 \\ URL: https://doi.org/10.5539/jas.v11n5p142
}

The research was financed by CAPES.

\begin{abstract}
The research had as objective to study the influence of the doses of nitrogen, phosphorus and potassium on soil fertility and nutritional status of yellow passion fruit plants. The experimental design was in randomized blocks in an incomplete fractioned factorial $1 / 2(4 \times 4 \times 4)$, with four doses of $\mathrm{N}\left(150,300,600\right.$ and $1200 \mathrm{Kg}^{-1} \mathrm{ha}^{-1} \mathrm{yr}^{-1}$ $\mathrm{N})$; four doses of $\mathrm{P}_{2} \mathrm{O}_{5}\left(200,400,800\right.$ and $\left.1600 \mathrm{~kg}^{-1} \mathrm{ha}^{-1} \mathrm{yr}^{-1}\right)$ and four doses of $\mathrm{K}_{2} \mathrm{O}\left(100,300,500\right.$ and $700 \mathrm{~kg}^{-1}$ $\left.\mathrm{ha}^{-1} \mathrm{yr}^{-1}\right)$. The fertilizers used were the ammonium nitrate $=32 \% \mathrm{~N}$; triple superphosphate $=44 \% \mathrm{P}_{2} \mathrm{O}_{5}$ and potassium chloride $=60 \% \mathrm{~K}_{2} \mathrm{O}$. In the fertility of the nitrogen fertilization increased the content of phosphorus and sulfur. The doses of $\mathrm{P}_{2} \mathrm{O}_{5}$ increased the concentration of $\mathrm{P}$ in the soil. The doses of $\mathrm{K}_{2} \mathrm{O}$ influenced the increase in the content of $\mathrm{K}$ in the soil in the harvest 2013/2014. There was an interaction of the doses of $\mathrm{N}$ and $\mathrm{K}_{2} \mathrm{O}$ in the availability of $\mathrm{K}$ in the soil in the harvest 2012/13 with the maximum levels of $\mathrm{K}$, in the doses of $200-400 \mathrm{~kg} \mathrm{~N} \mathrm{ha}^{-1}$ and 600 to $700 \mathrm{~kg} \mathrm{ha}^{-1}$ of $\mathrm{K}_{2} \mathrm{O}$. In the nutritional state the yellow passion fruit plants was influenced by the doses of $\mathrm{N}$ for the sulfur content of the leaves. The maximum content of $\mathrm{S}$ leaf concentration of $3.63 \mathrm{~g} \mathrm{~kg}^{-1}$ was obtained in the dose estimated at $1120 \mathrm{~kg} \mathrm{ha}^{-1}$ of $\mathrm{P}_{2} \mathrm{O}_{5}$.
\end{abstract}

Keywords: plants nutrition, Passiflora edulis Sims., sandy soils, fruit culture

\section{Introduction}

The Argisols constitute the soil class of greater spatial expression in the state of São Paulo, occupying $29 \%$ of its area. In general, the Argisols are susceptible to erosion by presenting textural gradient between the horizon A or $\mathrm{E}$ and the horizon B. These soils, especially when they present abrupt textural change, have low or very low resistance to erosion (Oliveira, 1999).

The morphology of these soils, mostly straight, with extensive length of rail, current vegetation cover of grass and land use by pasture and crops of sugar cane. In general, the original vegetation was removed, and currently there is a predominance of grass (Fushimi \& Nunes, 2012). Due to removal of native vegetation of these areas, and susceptibility to erosion, in general, the soils are exposed to environmental weathering that lead later, to the loss of horizon layer causing the loss of nutrients on the soil surface layer. Thus, aiming at the recovery of these areas for agriculture, it is necessary to carry out the mineral nutrition of the soil in search of improving soil fertility.

The yellow passion fruit (Passiflora edulis Sims.), represents approximately 97\% of national production of passion fruit plant. The cultivation of passion fruit plant is of great importance for small and medium-sized rural properties (Agrianual, 2017). In the state of São Paulo, due to the proximity of the major centers of consumption, the main form of marketing of passion fruit is the "in natura" fruit market (Vianna-Silva et al., 2008). And in the western region of the state the crop is being grown in areas with a predominance of sandy and degraded soils, where it was previously used for cattle grazing. 
The west region of São Paulo is among a few large producers of passion fruit of the state, it produced in 2017 around 225 thousand boxes of $16 \mathrm{~kg}$ of fruit, being one of the main crops among the fruit cultures produced in rural properties (IEA, 2018). In recent years the culture has gone through several modifications in its production technology, such as the handling manner and cultural managements. Among these modifications the planting of varieties is observed that are more productive and reduce the spacing. Even noting reasonable results in productivity in the region, it is a fact the necessity of changing the plants nutrition in the field, to adapt to the production system aiming to seek the maximum response in yield and fruits quality.

Of the nutrients, nitrogen $(\mathrm{N})$ and potassium $(\mathrm{K})$ are the nutrients absorbed in greater quantity by the passion fruit plant. Nitrogen has a structural function in the plant, being fundamental for the vegetative growth and production (Kliemann et al., 1986; Baumgartner, 1987), stimulating the development of flowering and fruitful buds. Thus, in its lacking the growth is slow, the size is reduced, with the presence of thin branches and in smaller numbers (Marteleto, 1991).

$\mathrm{K}$ is present in the plant in ionic form, acting as enzymatic activator and participating of various processes (Malavolta et al., 2006). The deficiency of this nutrient reduces the weight of the plant and the production of fruits, in addition to interfering with the quality of the fruits and the juice. In the passion fruit plant, the phosphorus (P), is an important nutrient in procedures for storage and transfer of energy. In its deficiency, the yellow passion fruit plants have low growth, smaller stem diameter, premature defoliation, slender tendrils and developed function and the fruits are green or yellowish uneven color (Rezende et al., 2008).

Thus, this research had as objective to study the influence of mineral nutrition with doses of nitrogen, phosphorus and potassium on interaction of nutrients in the soil fertility and nutritional status of yellow passion fruit plants, in São Paulo state region.

\section{Material and Methods}

\subsection{Characteristics of the Experimental Area}

The study was conducted in the field in two experimental areas located in the municipality of Presidente Prudente, West region of the state of São Paulo. The area 1, was in the experimental area of Apta (São Paulo Agency of Agribusiness Technology), in the period from September 2012 to July 2013. The area is located at 460 $\mathrm{m}$ of altitude, whose geographical coordinates are: Latitude $22^{\circ} 07^{\prime} 04^{\prime \prime} .8 \mathrm{~S}$ and longitude $51^{\circ} 23^{\prime} 01^{\prime \prime} .5 \mathrm{~W}$. The area 2 was carried out in a commercial area in the district of Montalvão, in the period from September 2013 to July 2014. The area is located at $460 \mathrm{~m}$ of altitude, whose geographical coordinates are: Latitude $22^{\circ} 05^{\prime} 04^{\prime \prime} .8 \mathrm{~S}$ and longitude $51^{\circ} 20^{\prime} 55^{\prime \prime} .5 \mathrm{~W}$.

The region's climate is Aw according to the Köeppen classification, with rainy summer and a dry winter, where the coldest month presents average temperature above $18{ }^{\circ} \mathrm{C}$. The annual precipitation is approximately 1250 $\mathrm{mm}$ (Cepagri, 2015). In Figure 1, there are the climatic data during the years 2012/2013 and 2013/2014, according to data from the meteorological station of UNESP, Presidente Prudente-SP. 

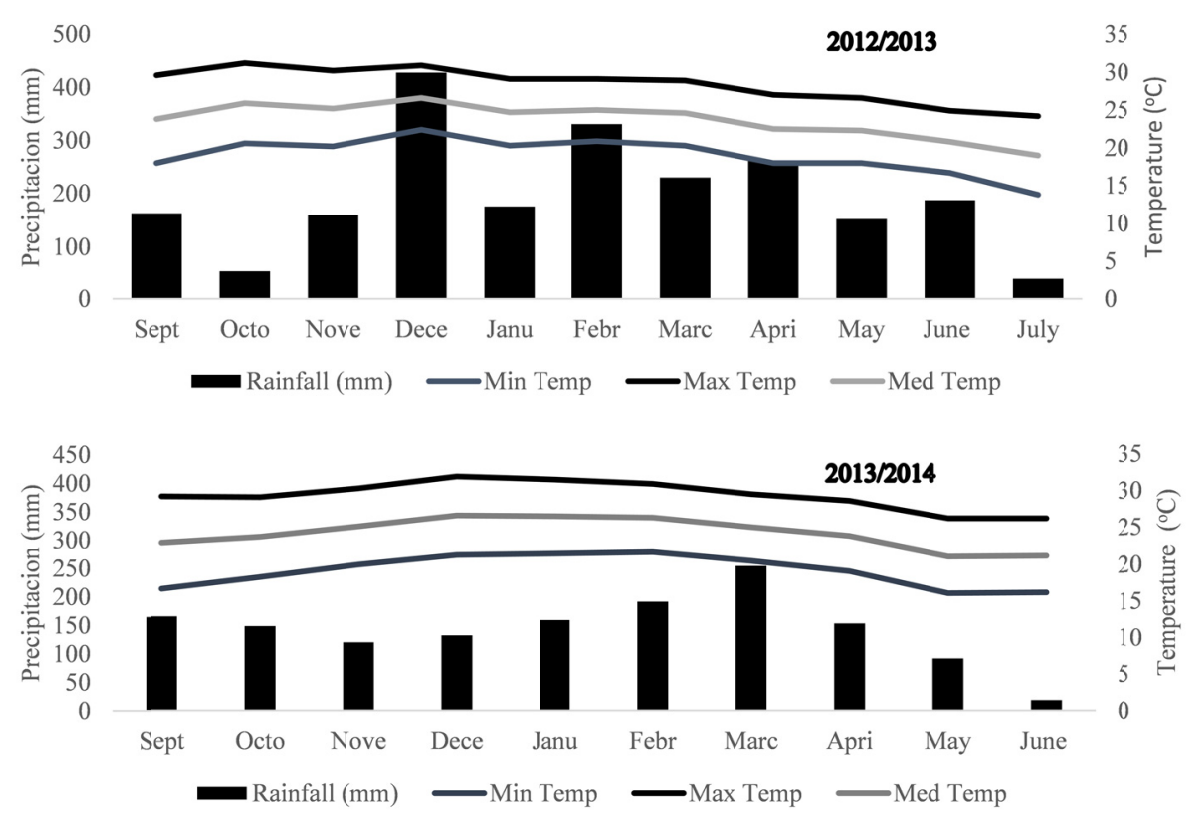

Figure 1. Precipitation date $(\mathrm{mm})$, temperature $\left({ }^{\circ} \mathrm{C}\right)$ and rainfall. Harvest $2012 / 2013$ and 2013/2014

\subsection{Physical and Chemical Analyses of Soil}

The soil of the area is classified as Red-Yellow Argisol, sandy texture, according to (IAC, 2016). In the physical analysis of soil texture in the layer of $0-20 \mathrm{~cm}$ depth the following levels were obtained: Apta area- total sand $\left(802 \mathrm{~g} \mathrm{~kg}^{-1}\right)$, silt $\left(74 \mathrm{~g} \mathrm{~kg}^{-1}\right)$ and clay $\left(124 \mathrm{~g} \mathrm{~kg}^{-1}\right)$, being classified as sandy textural class. In Montalvão area total sand $\left(848 \mathrm{~g} \mathrm{~kg}^{-1}\right)$, silt $\left(63 \mathrm{~g} \mathrm{~kg}^{-1}\right)$ and clay $\left(89 \mathrm{~g} \mathrm{~kg}^{-1}\right)$ were observed, being classified in the same as sandy textural class. The soil chemical attributes are shown in Table 1.

Table 1. Results of the soil chemical analysis in the $0-20 \mathrm{~cm}$ layer of sites before the experiments

\begin{tabular}{|c|c|c|c|c|c|c|c|c|c|c|c|}
\hline & \multirow{2}{*}{$\frac{\mathrm{pH}}{\mathrm{CaCl}_{2}}$} & \multirow{2}{*}{$\begin{array}{l}\text { O.M. } \\
\mathrm{g} \mathrm{dm}^{-3}\end{array}$} & $\mathrm{H}+\mathrm{Al}$ & SB & CEC & $\mathrm{V}$ & $\mathrm{P}$ & $\mathrm{SO}_{4}^{2-}$ & $\mathrm{K}$ & $\mathrm{Ca}$ & $\mathrm{Mg}$ \\
\hline & & & \multicolumn{2}{|c|}{---- $\mathrm{mmol}_{\mathrm{c}} \mathrm{dm}^{-3}$---- } & \multicolumn{2}{|c|}{-------- \% -------- } & \multicolumn{5}{|c|}{-------------------- $\mathrm{mmol}_{\mathrm{c}} \mathrm{dm}^{-3}$------------------ } \\
\hline Area 1. & 5.2 & 11.4 & 19.1 & 30.8 & 49.9 & 61.5 & 6.9 & 6.1 & 4.5 & 19 & 7.2 \\
\hline Area 2. & 5.0 & 13.4 & 25.5 & 45.5 & 71.0 & 64.1 & 117.0 & 3.8 & 4.1 & 34 & 7.5 \\
\hline
\end{tabular}

Note. $\mathrm{SB}=$ sum of bases; $\mathrm{CEC}=$ cation exchange capacity.

Source: Soils Laboratory, UNOESTE, SP.

\subsection{Experimental Design}

The experimental design was in randomized blocks in an incomplete fractioned factorial $1 / 2(4 \times 4 \times 4)$, proposed by Colwell (1978) and adapted by Andrade and Noleto (1986), being four doses of nitrogen $(150,300$, 600 and $\left.1200 \mathrm{Kg}^{-1} \mathrm{ha}^{-1} \mathrm{yr}^{-1} \mathrm{~N}\right)$; four doses of $\mathrm{P}_{2} \mathrm{O}_{5}\left(200,400,800\right.$ and $\left.1600 \mathrm{~kg}^{-1} \mathrm{ha}^{-1} \mathrm{yr}^{-1}\right)$ and four doses of $\mathrm{K}_{2} \mathrm{O}$ $\left(100,300,500\right.$ and $\left.700 \mathrm{~kg}^{-1} \mathrm{ha}^{-1} \mathrm{yr}^{-1}\right)$, totaling 32 plots, divided into 2 blocks. The applied doses were defined based on the Boletim Técnico 100, which is the manual recommendation of the passion fruit fertilizer in the state of São Paulo. In addition, the applied doses were recommended aiming at maximum productivity expected for passion fruit, based on the soil analysis of the areas.

\subsection{Production of Seedlings of Yellow Passion Fruit}

The seedlings were developed for the harvests 2012/2013 and 2013/2014 using the variety Sul-Brasil afruvec, whose seedlings were formed and developed in experimental greenhouse of APTA in the months from April to August. The greenhouse covered with transparent plastic film and coated on both sides with anti-aphid screen and covered inside with shading-net 50\%.

The seeds of yellow passion fruit were removed from fruits collected from commercial plantation placed to germinate in styrofoam trays of 200 divisions. After germination, the seedlings were transplanted and placed in a 
2-liter, black, plastic bag polyethylene and perforated, filled with commercial substrate Plantmax ${ }^{\circledR}$. During the cycle were 3 fungicide applications performed (Azoxystrobin) to avoid the development of diseases.

The seedlings in plastic bag received $6 \mathrm{~g}$ of commercial fertilizer Basacote-Mini $3 \mathrm{M}^{\mathbb{R}}$ for the development during the handling period. The chemical composition of Basacote presented as a guarantee: $13 \% \mathrm{~N} ; 6 \% \mathrm{P}_{2} \mathrm{O}_{5}$; $16 \% \mathrm{~K}_{2} \mathrm{O} ; 1.4 \% \mathrm{Mg} ; 10 \% \mathrm{~S} ; 0.02 \% \mathrm{~B} ; 0.15 \% \mathrm{Fe} ; 0.06 \mathrm{Mn}$ and $0.05 \% \mathrm{Cu}$. During the development the seedlings were irrigated until the substrate reached the field capacity. In the month of September, the seedlings were taken to the field with approximately 2 meters in height for the planting.

The area was prepared in advance of 90 days, where it was first held the first soil tillage, and subsequently the demarcation of the experimental area, such as the opening of the grooves of planting. After the soil preparation the fences and the bamboos in the area for identification of the plots were placed. The liming was performed 90 days before planting, by applying the dolomitic limestone according to soil analysis (Table 1) to increase the base saturation to $80 \%$.

The passion fruit plant was planted at $3.30 \mathrm{~m}$ spacing between rows $\times 2.0$ m between plants $\left(1515\right.$ plants ha $\left.^{-1}\right)$, with useful portion of $39.6 \mathrm{~m}^{2}$, being formed of six useful plants, the plants of the central row. The plot was constituted by three rows, totaling 18 plants, being 6 plants in each row, being the total of $118.8 \mathrm{~m}^{2}$ plot, occupying a total area $3801.6 \mathrm{~m}^{2}$.

In the harvests 2012/2013 and 2013/2014 the production system adopted for the passion fruit plant was in dryland conditions. For weed control 2 applications were performed of herbicides Paraquat (Gramonoxe 200) and Finale (Glusofinate of ammonium salt). In the diseases control 7 preventive fungicide applications were performed based on copper oxychloride (Recop), Mancozebe (Dithane NT) and Tionato Methyl (Cercobin 700 WP) and an application of Pyrethroid (Decis $25 \mathrm{CE}$ ) for the pests' control.

\subsection{Fertilization Management}

The mineral fertilizers used as source of $\mathrm{N}, \mathrm{P}$ and $\mathrm{K}$ were the ammonium nitrate $=32 \% \mathrm{~N}$; triple superphosphate $(\mathrm{SFR})=42 \% \mathrm{P}_{2} \mathrm{O}_{5}$ and potassium chloride $(\mathrm{KCI})=60 \% \mathrm{~K}_{2} \mathrm{O}$. In triple superphosphate fertilization $\left(44 \% \mathrm{P}_{2} \mathrm{O}_{5}\right)$ was applied in a single dose in the furrow at planting, along with the micronutrients (50 $\mathrm{g}$ of FTE BR 12/ plant). The nitrogen $(\mathrm{N})$ and potassium $(\mathrm{K})$ were divided into six soil covers (October to April) in each experiment, in increasing doses accompanying the plants development to minimize losses by leaching in soil and improve the utilization of nutrients.

\subsection{Characteristics Evaluated}

The soil samplings were carried out at 270 DAP-days after planting in the months of June 2013 and 2014, collecting the soil with the use of probe type soil at a depth of $0-20 \mathrm{~cm}$ (one sample from each side of the six useful plants), approximately $15 \mathrm{~cm}$ from the stem of useful plants, forming a composite sample per treatment. All samples were packed and duly identified and brought to the Soil Laboratory of Unoeste. The samples were dried, and the chemical contents of the soil were determined according to the methodology of Raji et al. (2001) of $\mathrm{pH}\left(\mathrm{CaCl}_{2}\right)$; O.M.; $\mathrm{H}+\mathrm{Al} ; \mathrm{SB} ; \mathrm{CEC} ; \mathrm{V} \%$; $\mathrm{P} ; \mathrm{SO}_{4}{ }^{2-} ; \mathrm{K} ; \mathrm{Ca}$ and $\mathrm{Mg}$.

The foliar analyzes were performed by collecting the fourth leaf from 180 DAP-days after planting, of median branches without fruits, obtaining a compound sample by treatment, according to the methodology of Malavolta et al. (1989). The fresh leaves were washed in distilled water containing a little bit of detergent; then, they were rinsed with distilled water, in successive portions to remove all the detergent, and then placed on absorbent paper.

The leaf samples were placed in paper bags and put out to dry in an oven with forced air circulation at a temperature of $65^{\circ} \mathrm{C}$. The samples were ground using the milling type Wiley. After the samples processing, the chemical analyses were carried out for the determination of the levels of nutrients $(\mathrm{N}, \mathrm{P}, \mathrm{K}, \mathrm{Ca}, \mathrm{Mg}$ and $\mathrm{S}$ ) according to the methodology described by Malavolta et al. (1997).

\subsection{Statistical Analysis}

The obtained data were analyzed by a mathematical model: $y=b_{0}+b_{11} N+b_{22} P^{2}+b_{3} K+b_{33} K^{2}+b_{12} N P+b_{13} N K$ $+b_{23} \mathrm{PK}$, subjected to analysis of variance by the statistical program SAS (Statistical Analyzes System) 9.2 (SAS, 2010), and the variables whose response was significant to the doses were analyzed by regression testing for the significance level of $p<0.05 ;<0.10 \%$. The results that make interaction among the nutrients $\mathrm{N}, \mathrm{P}$ and $\mathrm{K}$ were analyzed by the surface response (Banzatto \& Kronka, 2006). 


\section{Results and Discussion}

\subsection{Effect of NPK Fertilization on Soil}

In the soil fertility significant responses were observed of nitrogen, phosphorus and potassium in the increase of the mineral concentration of soil in P, S and K in the harvest of 2012/13 and K in the harvest 2013/2014. The results of the analysis of soil nutrients are presented in Figures 2, 3, 4 and 5.
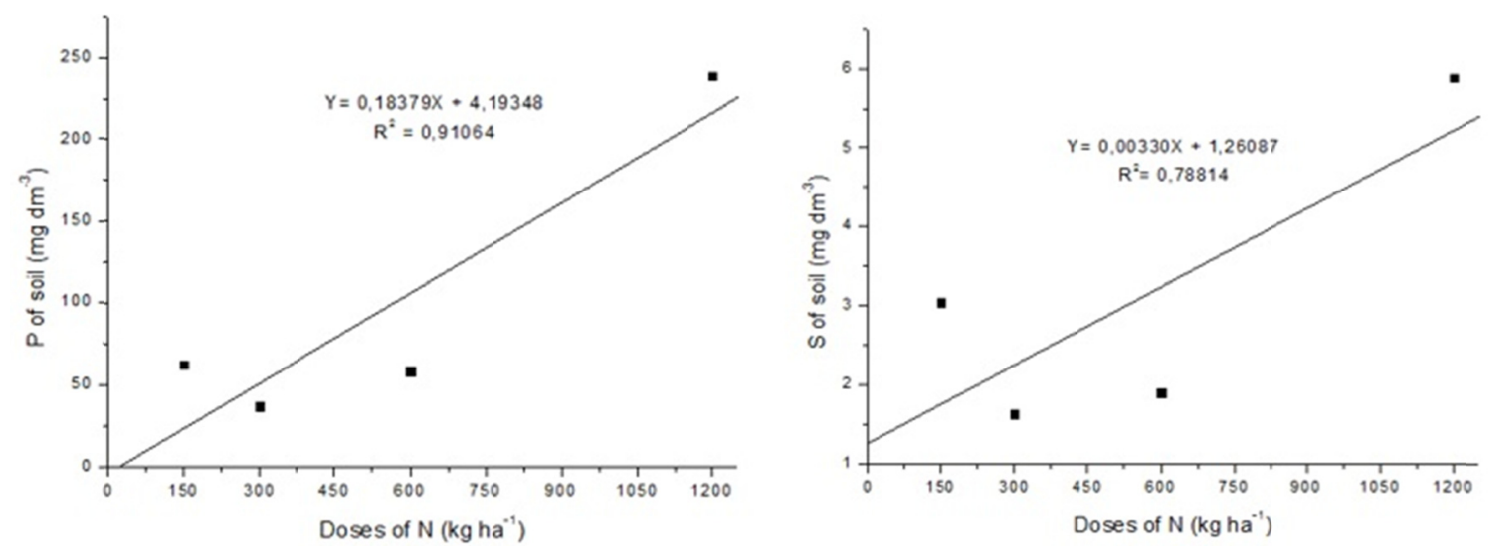

Figure 2. Phosphorus (P) and sulfur (S) of the soil in response to nitrogen fertilization-Harvest 2012/2013

The $\mathrm{N}$ doses influenced the increased availability of $\mathrm{N}$ and $\mathrm{S}$ on the soil, observed in Figure 1. The higher concentration of $\mathrm{N}$ and $\mathrm{S}$ in the soil obtained by fertilization of $\mathrm{N}$, allows the greater absorption of these two nutrients by the leaves, consequently, the plants can develop better resulting in a higher productivity of fruits.

According to Marschner (1995) N stimulates the increased absorption of $\mathrm{P}$, due to the increased growth of rootlets, the roots that absorb water and nutrients in plants, provided by fertilization with $\mathrm{N}$.

In the sulfur content of the soil linear response was noted to the $\mathrm{N}$ applied in the soil. The maximum dose of $1200 \mathrm{~kg} \mathrm{~N} \mathrm{ha}^{-1}$ provided the highest availability of sulfur with $5.88 \mathrm{mg} \mathrm{dm}^{-3}$. The plants with a greater supply of $\mathrm{N}$ grow better and have a higher demand of S (Grant et al., 2004; Hawkesford \& De Kok, 2006). The interaction between $\mathrm{N}$ and $\mathrm{S}$ is also reported due to the proteins production. Adjustment of the assimilation of interaction between $\mathrm{S}$ and the function of $\mathrm{N}$.

in the metabolism to coordinate the flow of two elements is important because plants tend relatively to use a fixed ratio of N/S for the proteins assimilation (Hesse et al., 2004; Carfagna et al., 2011).

The doses of $\mathrm{P}_{2} \mathrm{O}_{5}$ resulted in an increase in the $\mathrm{P}$ content of the soil, adjusting the effect of doses to the linear regression model, with the maximum accumulation of phosphorus in the soil of $238.78 \mathrm{mg} \mathrm{dm}^{-3}$ in dose $1600 \mathrm{~kg}$ ha $^{-1}$ of $\mathrm{P}_{2} \mathrm{O}_{5}$ (Figure 3).

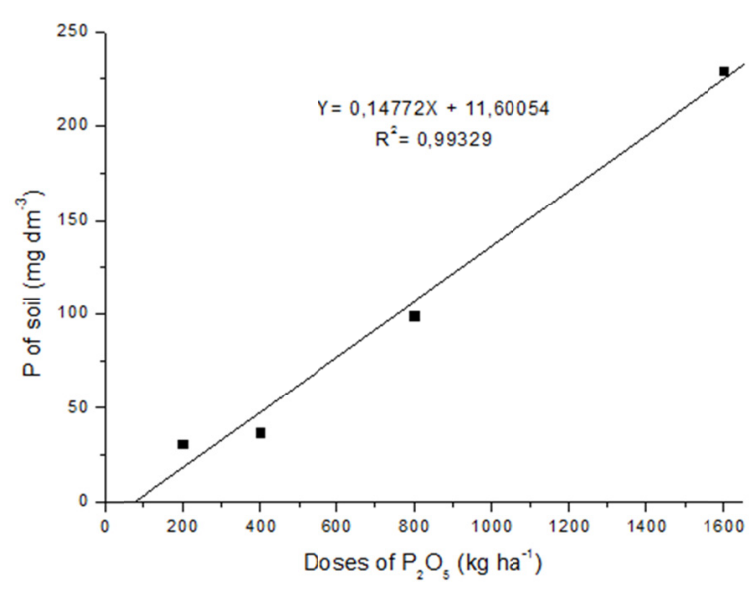

Figure 3. Phosphorus (P) of the soil in response to doses of $\mathrm{P}_{2} \mathrm{O}_{5}$-Harvest 2012/2013 
The response to this attribute was due to good rainfall during the 2012/2013 harvest (Figure 1), combined with the time period of 9 months (from the planting of seedlings to the soil collection) to release the $\mathrm{P}$, favoring a greater availability of nutrients in the soil. Borges et al. (2002) also observed an increase in the levels of $P$ in the soil similar to the doses of $\mathrm{P}_{2} \mathrm{O}_{5}$ applied in Yellow Latosol, sandy clay loam. The average content of $\mathrm{P}$ of the soil increased in relation to the initial content in the first year of passion fruit plant cultivation, raising $5 \mathrm{mg} \mathrm{dm}^{-3}$ to $107 \mathrm{mg} \mathrm{dm}^{-3}$ of $\mathrm{P}$, in the soil containing $620 \mathrm{~g}_{\text {of }}$ sand $\mathrm{kg}^{-1}$.

Regarding the $\mathrm{K}$ of the soil there was a significant effect on the interaction among the doses, subjected in response surface model of the doses of $\mathrm{N}$ and $\mathrm{K}_{2} \mathrm{O}$. According to the answer observed in the soil, nitrogen and potassium fertilization combined had a direct influence on the availability of $\mathrm{K}$ in the soil found in Figure 4.

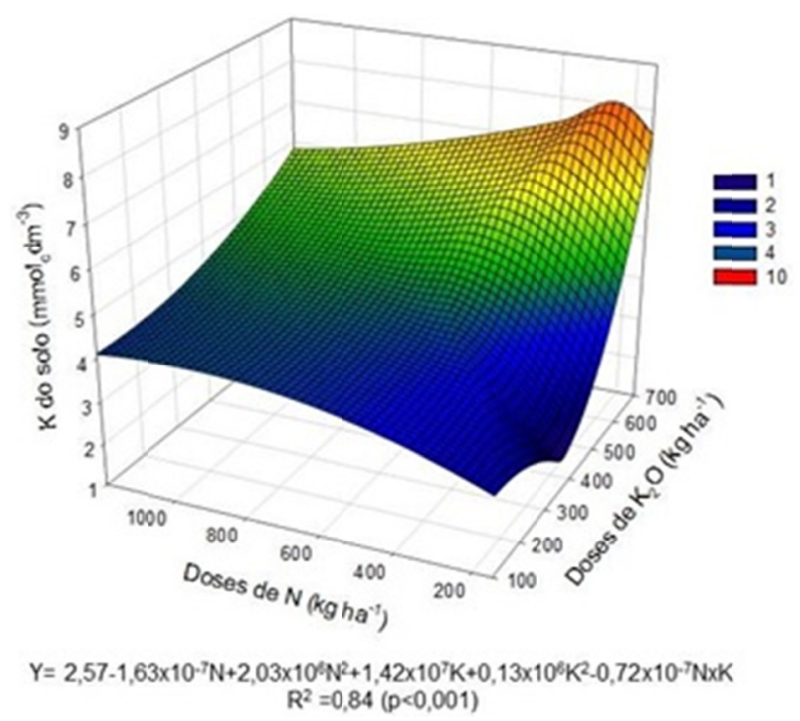

Figure 4. Surface response to potassium of the of the soil in response to doses of N and $\mathrm{K}_{2} \mathrm{O}$-Harvest 2012/2013

It is possible to see that the availability of $\mathrm{K}$ in the soil increased with the application of lower doses of $\mathrm{N}$ (200-400 kg N ha $\left.{ }^{-1}\right)$ combined the highest doses of $\mathrm{K}_{2}\left(600-700 \mathrm{~kg} \mathrm{ha}^{-1}\right.$ of $\left.\mathrm{K}_{2} \mathrm{O}\right)$. In the experiment conducted in sandy soil antagonist effect was found between $\mathrm{N}$ and $\mathrm{K}$, excessive nitrogen fertilization reduced the availability of $\mathrm{K}$ in the soil.

One of the explanations for this response is that the increases of $\mathrm{N}$ stimulate a greater vegetative and reproductive development of passion fruit plant, consequently there is a greater extraction of $\mathrm{K}$ from the soil due to the increasing demand of nutrients by the plants, having a direct effect on the decrease in the availability of K. And the doses of $\mathrm{K}_{2} \mathrm{O}$ resulted in a linear increase of the concentration of nutrients in the soil, since it is known that the potassium is a movable element in the soil and mineral fertilization provides the cation $\mathrm{K}^{+}$, the form absorbed by the roots of the plant. Another possible effect for the decrease of the contents $\mathrm{K}$ in the soil, is that increases of $\mathrm{NH}_{4}{ }^{+}$(ammonia) source of $\mathrm{N}$ used, contributed to the reduction of transport of $\mathrm{K}^{+}$by the plant. According to Hoppen et al. (2010) the unbalance in the $\mathrm{NH}_{4}{ }^{+}$adsorption in the transport can contribute in the ammonium toxicity and reduction in the levels of $\mathrm{K}^{+}$by competition among the cations.

In the harvest of 2013/2014 there was direct response in $\mathrm{K}$ of the soil with application of the doses of $\mathrm{K}_{2} \mathrm{O}$, adjusting the doses to the linear regression model, that is, as the doses of $\mathrm{K}_{2} \mathrm{O}$ increased the levels of $\mathrm{K}$ increased in the soil (Figure 5). 


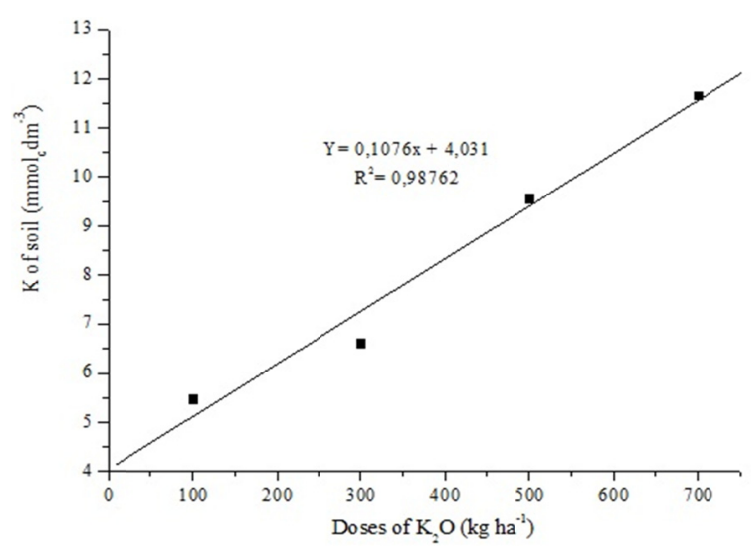

Figure 5. Potassium of the soil in response to potassium fertilization-Harvest 2013/2014

The maximum response for $\mathrm{K}$ of the soil of $11.67 \mathrm{mmol}_{\mathrm{c}} \mathrm{dm}^{-3}$ was verified with the application of the maximum dose of potassium of $700 \mathrm{~kg} \mathrm{ha}^{-1}$ of $\mathrm{K}_{2} \mathrm{O}$. According to Emari et al. (2007) the concentration of $\mathrm{K}$ in the soil is lower than $20 \mathrm{mg} \mathrm{L}^{-1}$, even in well fertilized soils. And the amount of potassium can be depleted in a few hours or a few days, in case the exchangeable potassium replacement was not performed.

In this context, the replacement is done mainly with the exchangeable $\mathrm{K}$ of the soil. In addition to the quantity, the rapidity in the replacement is also essential for the plant's nutrition. Being important the fertilization with the element in the soil to maintain the nutrient in the system. Ciotta et al. (2002) in tillage soil for over 20 years, it has been observed that the higher the concentration of exchangeable $\mathrm{K}$ in the soil, the higher the contents of $\mathrm{K}$ were in the solution in samples collected from different depths of the soil.

\subsection{Influence of Mineral Nutrition on the Nutritional Status of Plants}

In the analysis of leaves of nutrients positive response was found of leaf nitrogen with increases of $\mathrm{N}$ doses, adjusting the response to the linear regression model, found in figure 6 . The other foliar macronutrients were not influenced by soil fertilization with NPK of the soil in the harvest 2012/2013. It was not verified response on nutritional status for any of the nutrients in the harvest 2013/2014, possibly due to the incidence of viral infection of passion fruit plant (CABMV) that occurred in the area, which influenced the possible responses in the plant's nutrition. The disease is caused by a virus, scientific name Cowpea aphid-borne mosaic virus (CABMV), which is transmitted by aphids of the species: Aphis gossypii, Mysus persicae and Toxoptera citricidus.

The virus feeds from plant nutrients, leaving it weakened causing chlorosis of younger leaves and when attack occurs in orchards under formation, they can cause the fall of the leaves, the fruits are hardened and fall leading to plant death in severe incidence of the disease.

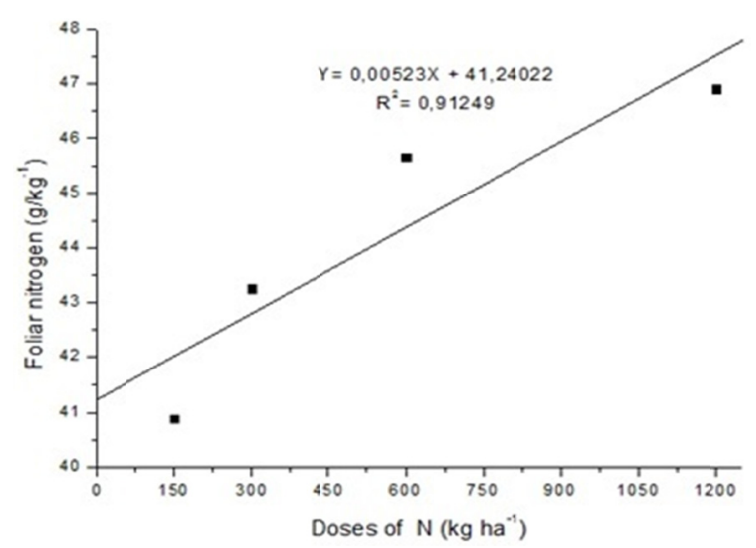

Figure 6. Leaf nitrogen of yellow passion fruit plants in response to nitrogen fertilization-Harvest 2012/2013

There was an increase in leaf $\mathrm{N}$ content directly influenced to the doses applied, with maximum foliar value of $\mathrm{N}$ $46.90 \mathrm{~g} \mathrm{~kg}^{-1}$ obtained at a dose of $1200 \mathrm{~kg} \mathrm{ha}^{-1}$ of N. Positive results were also obtained by Carvalho et al. (2002) 
and Venâncio et al. (2013) with yellow passion fruit on the foliar $\mathrm{N}$, the authors obtained a linear response of $46.4 \mathrm{~g} \mathrm{~kg}^{-1}$ of $\mathrm{N}$ and $40.49 \mathrm{~g} \mathrm{~kg}^{-1}$ of N, respectively with the doses of 1083 and $210 \mathrm{~kg} \mathrm{ha}^{-1}$ year-1 of N.

The $\mathrm{S}$ foliar content in Figure 7 was influenced by the doses of $\mathrm{P}_{2} \mathrm{O}_{5}$ applied in the soil, responding to the increase of the same, being adjusted to the quadratic regression model. The maximum leaf concentration was $3.63 \mathrm{~g} \mathrm{~kg}^{-1}$ of $\mathrm{S}$ in estimated dose of $1120 \mathrm{~kg} \mathrm{ha}^{-1}$ of $\mathrm{P}_{2} \mathrm{O}_{5}$.

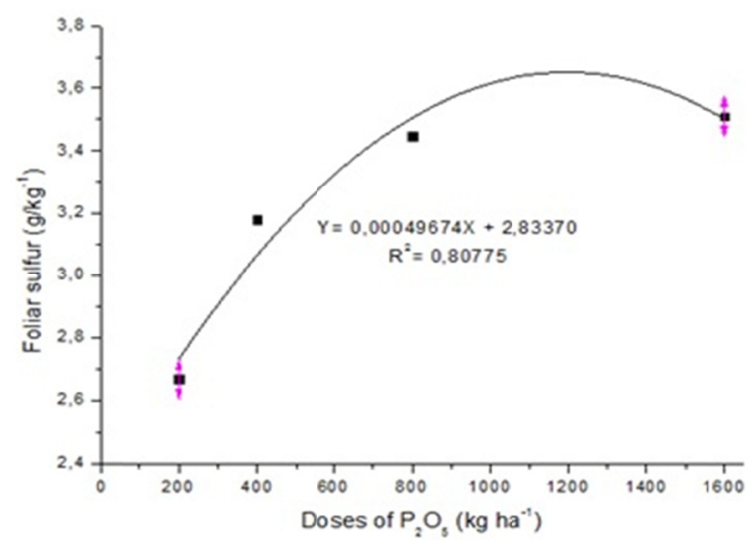

Figure 7. Foliar Sulfur of yellow passion fruit plants in response to phosphate fertilization-Harvest 2012/2013

The positive interaction of $\mathrm{P}$ in the absorption of macronutrients, among them $\mathrm{S}$, may be associated with the improvement in the development and production of crops with phosphate fertilization. Increase in the development and productivity requires more nutrients compared to low production (Fageria, 2009). According to Prado (2013), the leaves are usually many times more active than the roots in the sulfur assimilation. And the adding together of $\mathrm{P}$ and $\mathrm{S}$ has a high positive response in the growth and development of crops.

\section{Conclusion}

In the fertility of the nitrogen fertilization increased the content of phosphorus and sulfur. The doses of $\mathrm{P}_{2} \mathrm{O}_{5}$ increased the concentration of $\mathrm{P}$ in the soil. The doses of $\mathrm{K}_{2} \mathrm{O}$ influenced the increase in the content of $\mathrm{K}$ in the soil in the harvest 2013/2014. There was an interaction of the doses of $\mathrm{N}$ and $\mathrm{K}_{2} \mathrm{O}$ in the availability of $\mathrm{K}$ in the soil in the harvest 2012/13 with the maximum levels of $\mathrm{K}$, in the doses of 200-400 kg N ha ${ }^{-1}$ and 600 to $700 \mathrm{~kg}$ $\mathrm{ha}^{-1}$ of $\mathrm{K}_{2} \mathrm{O}$.

In the nutritional state the yellow passion fruit plants was influenced by the doses of $\mathrm{N}$ for the sulfur content of the leaves. The maximum content of $\mathrm{S}$ leaf concentration of $3.63 \mathrm{~g} \mathrm{~kg}^{-1}$ was obtained in the dose estimated at $1120 \mathrm{~kg} \mathrm{ha}^{-1}$ of $\mathrm{P}_{2} \mathrm{O}_{5}$.

\section{References}

Agrianual. (2017). Anuário da agricultura brasileira (22th ed.). São Paulo, SP: Agra FNP Pesquisas.

Andrade, D. F., \& Noleto, A. Q. (1986). Exemplos de fatoriais fracionados (1/2) $4^{3}$ e (1/4) $4^{4}$ para ajuste de modelos polinomiais quadráticos. Pesquisa Pecuária Brasileira, 21, 677-680.

Banzatto, D. A., \& Kronka, S. N. (2006). Experimentação agrícola. Jaboticabal, SP: FUNEP.

Baumgartner, J. G. (1987). Nutrição e Adubação do Maracujá: Maracujá (1st ed.). Ribeirão Preto, SP: Legis Summa Ed.

Borges, A. L., Caldas, R. C., Lima, A. A., \& Almeida, I. E. (2002). Efeito de doses de NPK sobre os teores de nutrientes nas folhas e no solo, e na produtividade do maracujazeiro amarelo. Revista Brasileira de Fruticultura, 24, 208-213. https://doi.org/10.1590/S0100-29452002000100045

Carfagna, S., Vona, V., Di Martino, V., \& Esposito, S. (2011). Nitrogen assimilation and cysteine biosynthesis in barley: Evidence for root sulphur assimilation upon recovery from $\mathrm{N}$ deprivation. Environmental and Experimental Botany, 71, 18-24. https://doi.org/10.1016/j.envexpbot.2010.10.008

Carvalho, A. J. C., Monnerat, P. H., Martins, D. P., \& Bernardo, S. (1999). Produtividade e qualidade do maracujazeiro-amarelo em resposta à adubação potássica sob lâminas de irrigação. Revista Brasileira de Fruticultura, 21, 333-337. 
Cepagri. (2015). Clima dos municípios paulistas. Retrieved from http://www.cpa.unicamp.br/outras-informa ções/clima-dos-municípios-paulista.html

Ciotta, M., Bayer, C., Ernani, P. R., Fontoura, S. M. V., Albuquerque, J. A., \& Wobeto, C. (2002). Acidificação de um Latossolo sob plantio direto. Revista Brasileira de Ciências do Solo, 26, 1055-1064. https://doi.org/10.1590/S0100-06832002000400023

Colwell, J. D. (1978). Computations for studies of soil fertility and fertilizer requirements. Commonw. Agric. Bur., London, UK.

Ernani, P. R., Almeida, J. A., \& Santos, F. C. (2007). Formas de potássio no solo: Fertilidade do solo (1st ed.). Viçosa, MG: SBCS.

Fageria, N. K. (2009). Phosphorus. The use of nutrients in crop plants (3rd ed.). New York, NY: CRC Press.

Fushimi, M., \& Nunes, J. O. R. (2012). Principais classes de solos do município de Presidente Prudente-SP: identificação e caracterização. Boletim Goiano de Geografia, 32, 45-58. https://doi.org/10.5216/bgg. v32i1.18955

Grant, C. A., Johnston, A. M., \& Clayton, N, G. W. (2003). Sulphur fertilizer and tillage effects on early season sulphur availability and N:S ratio in canola in western Canada. Canadien Journal Soil Sciencies, 83, 451-463. https://doi.org/10.4141/S02-046

Hawkesford, M. J., \& De Kok, L. J. (2006). Managing sulphur metabolism in plants. Plant Cell Environmental, 29, 382-395. https://doi.org/10.1111/j.1365-3040.2005.01470.x

Hesse, H., V., Nikiforova, V., Gakière, B., \& Hoefgen, R. (2004). Molecular analysis and control of cysteine biosynthesis: Integration of nitrogen and sulphur metabolism. Journal Experimental Botany, 55, 1283-1292. https://doi.org/10.1093/jxb/erh136

Hoppen, F. T., Cuin, T. A., Pedas, P., Hegelund, J. N., Shabala, S., Schjoerring, J. K., \& Jahnt, T. P. (2010). Competition between uptake of ammonium and potassium in barley and Arabidopsis roots: Molecular mechanisms and physiological consequences. Journal of Experimental Botany, 61, 2303-2315. https://doi.org/10.1093/jxb/erq057

IAC (Instituto Agronômico de Campinas). (2016). Retrieved from http://www.iac.sp.gov.br/solossp/pdf/ Argissolos.pdf

IEA (Instituto de Economia Agrícola). (2018). Retrieved from http://ciagri.iea.sp.gov.br/nial/subjetiva.aspx? cod_sis=1\&idioma $=1$

Kliemann, H. J., Campelo Junior, J. H., Azevedo, J. A. De, Guilherme, M. R., \& Gen, P. J. de C. (1986). Nutrição mineral e adubação do maracujazeiro (Passiflora edulis Sims): Nutrição mineral e adubação de frutiferas tropicais no Brasil. Campinas, SP: Fundação Cargill.

Malavolta, E. (2006). Manual de nutrição mineral de plantas. Piracicaba, SP: Editora Agronômica Ceres Ltda.

Malavolta, E., Vitti, G. C., \& Oliveira, S. A. (1997). Metodologia para análise de elementos em material vegetal: Avaliação do estado nutricional das plantas: princípios e Aplicações (2nd ed.). Piracicaba, SP: POTAFOS.

Malavolta, E., Vitti, G. C., \& Oliveira, S. A. (1989). Avaliação do estado nutricional das plantas: princípios e aplicações. Piracicaba, SP: POTAFOS.

Marschner, H. (1995). Mineral nutrition of higher plants (2nd ed.). New York, NY: Academic Press. https://doi.org/10.1016/B978-012473542-2/50015-8

Marteleto, L. O. (1991). Nutrição e adubação. A cultura do maracujá no Brasil (1st ed.). Jaboticabal, SP: FUNEP.

Oliveira, J. B. de. (1999). Solos do Estado de São Paulo: Descrição das classes registradas no mapa pedológico. Campinas, SP: Instituto Agronômico.

Prado, C. H. B. de A. (2013). Utilização e fonte de macronutrientes: Aquisição de nutrientes minerais na solução do solo. São Carlos, SP: Tipographia Editora Expressa.

Raij, B., Andrade, J. C., Cantarella, H., \& Quaggio, J. A. (2001). Análise química para avaliação de fertilidade de solos tropicais. Campinas, SP: IAC.

Rezende, A. V., Sanziniwicz, C., Sena, M. C., Braga, M. F., Junqueira, N. T. V., \& Faleiro, F. G. (2008). Manejo do solo, nutrição e adubação do maracujazeiro-azedo na região do cerrado. Planaltina: Embrapa Cerrados. 
São José, A. R. (1994). A cultura do maracujazeiro: práticas de cultivo e mercado. Vitória da Conquista, BA: UESB.

SAS Institute. (2010). SAS 9.2 User's guide (2nd ed). NC, USA: Cary.

Venâncio, J. B., Rodrigues, E. T., Silveira, M. V., Araújo, W. F., Chagas, E. A., \& Castro, A. M. (2013). Produção, qualidade dos frutos e teores de nitrogênio foliar em maracujazeiro-amarelo sob adubação nitrogenada. Cientifica, 41, 11-20.

Vianna-Silva, T., Resende, E. D., Viana, A. P., Pereira, S. M. de F., Carlos, L. de A., \& Letícia Vitorazi, L. (2008). Qualidade do suco de maracujá-amarelo em diferentes épocas de colheita. Ciência e Tecnologia de Alimentos, 28, 545-550. https://doi.org/10.1590/S0101-20612008000300007

\section{Copyrights}

Copyright for this article is retained by the author(s), with first publication rights granted to the journal.

This is an open-access article distributed under the terms and conditions of the Creative Commons Attribution license (http://creativecommons.org/licenses/by/4.0/). 